\title{
Thyroid dysfunction induced by immune checkpoint inhibitors and tumor progression in neoadjuvant therapy for Non-Small Cell Lung Cancer: a case report and literature review
}

\author{
Xinyi Li \\ Peking University Health Science Center \\ Xun Wang \\ Peking University People's Hospital \\ Shaodong Wang \\ Peking University People's Hospital \\ Yanguo Liu \\ Peking University People's Hospital \\ Ruilin Wang \\ Peking University Health Science Center \\ Yi Liu \\ Peking University People's Hospital \\ Lin Huang \\ Peking University People's Hospital \\ Yufei Feng \\ Peking University People's Hospital \\ Xiaohui Xie ( $\nabla$ xxhrenee@bjmu.edu.cn) \\ Peking University \\ Luwen Shi \\ Peking University Health Science Center
}

\section{Research Article}

Keywords: Thyroid dysfunction, immune-related adverse events (irAEs), tumor progression, neoadjuvant therapy, non-small cell lung cancer (NSCLC),

Posted Date: February 2nd, 2022

DOI: https://doi.org/10.21203/rs.3.rs-1286606/v1

License: (c) (1) This work is licensed under a Creative Commons Attribution 4.0 International License. Read Full License 


\section{Abstract}

Background

The immune checkpoint inhibitors (ICls) targeting anti-programmed death receptor 1 (PD-1) and its ligand (PD-L1) has shown promising value in resectable (stage I-IIIA) or potentially resectable (stage IIIB) non-small-cell lung cancer (NSCLC). However, the immune-related adverse events (irAEs) and tumor progression in neoadjuvant therapy are of great concern, which might result in surgical delay or failure to undergo resection. In addition, the association between the development of thyroid dysfunction and the cancer outcomes was controversial and highly concerned.

Case presentation

A 59-year-old male with NSCLC (squamous, IIIA) was received neoadjuvant immunotherapy in combination with chemotherapy before surgery. However, IClsrelated thyroid dysfunction occurred, and the patient experienced transient hyperthyroidism then transformed into hypothyroidism. Moreover, the patient suffered from tumor progression and was unable to undergo resection. He refused immunotherapy and was given chemotherapy for the subsequent treatment.

\section{Conclusions}

We presented the case of ICls-related thyroid dysfunction and failure to undergo resection because of poor efficacy to elucidate clinical features of irAEs and tumor progression in the neoadjuvant immunotherapy, so as to timely and properly monitor the efficacy and safety of neoadjuvant immunotherapy in resectable NSCLC patients in clinical practice. Our case also demonstrated that the development of ICls-related thyroid dysfunction might not predict the good efficacy of ICls in NSCLC.

\section{Introduction}

Lung cancer (LC) remains the leading cause of cancer death worldwide with 8.2 million deaths per year[1]. Despite the advancement of surgery having improved the 5-year overall survival in early and locally advanced non-small-cell lung cancer (NSCLC)[2], there is still almost $50 \%$ of patients subsequently experienced recurrence after surgery alone[3]. The addition of neoadjuvant or adjuvant therapy provides the improvement of $5 \%$ in 5 -year overall survival[4].

The immune checkpoint inhibitors (ICls) targeting anti-programmed death receptor 1 (PD-1) and its ligand (PD-L1) have revolutionized the treatment for advanced NSCLC [5, 6]. Several trials have reported the value of ICls in resectable (stage I-IIIA) or potentially resectable (stage IIIB) NSCLC with major pathological response as primary endpoint[7-9]. However, there are several considerations that ICls might have some significant toxicities resulting in surgery delay and/or the intraoperative complications. Tumor progression might occur in some cases due to the toxicities or poor efficacy[10,11].

Endocrine adverse events are among the most common toxicities experienced from ICls and the most common endocrine organ affected by ICls is the thyroid[12]. Previous data have illustrated that the thyroid dysfunction during anti-PD1 therapy is associated with improved outcomes and may serve as a parameter to predict a better therapy response[13]. However, there are some data opposed to this hypothesis[14]. Here, we reported a case of thyroid dysfunction and tumor progression after the treatment of the PD-1 inhibitor pembrolizumab and its clinical features and management in stage IIIA NSCLC. We also review the literature to comprehend the thyroid dysfunction, the tumor progression, and their association in immunotherapy for NSCLC.

\section{Case Presentation}

In September 2020, a 59-year-old male with a 30-pack-year history of smoking was transferred to Peking University People's Hospital. He had experienced shortness of breath after activity without any obvious causes for almost eight months, but had no chest pain, cough, expectoration and fever. Chest CT scanning found central-type occupation of left upper lobe with atelectasis in other hospital, and PET-CT was performed, showing that the central space was occupied in the upper lobe of the left lung, the lymph nodes in group 6 were slightly larger, and no abnormal uptake was found. The pathological puncture diagnosis was squamous carcinoma. Chest CT was performed again in our hospital, revealing that the volume of the upper lobe of the left lung decreased and consolidated, the upper lobe bronchus of the left lung was blocked and the soft tissue density shadow extended to the left main bronchus and the lower lobe bronchus of the left lung, resulting in a slight stenosis of the lower lobe bronchi, which indicating the malignant lesion happened and multiple lymph nodes partially enlarged in mediastinal (Figure 1A). The clinical stage was T4NOMO(IIIA). The patient's general condition was assessed to be satisfactory, evaluated by Eastern Cooperative Oncology Group Performance Status (ECOG PS score=1). The thyroid hormone of this patient was all in the normal range. The free triiodothyronine (FT3) was $4.55 \mathrm{pmol} / \mathrm{L}$, free thyroxine (FT4) was $17.16 \mathrm{pmol} / \mathrm{L}$, triiodothyronine (T3) was $136.05 \mathrm{ng} / \mathrm{dL}$, thyroxine (T4) was $10.6 \mu \mathrm{g} / \mathrm{dL}$, thyroid stimulating hormone (TSH) was $1.016 \mathrm{mIU} / \mathrm{L}$, and thyroglobulin antibodies (TGAb) was $21.8 \mathrm{IU} / \mathrm{mL}$.

He underwent neoadjuvant therapy before surgery with pembrolizumab (200 mg, day1) plus carboplatin (450 mg, day 1$)$ and gemcitabine (2.2 g, day 1,8$)$ for two cycles from September 29 to October 20, 2020.

On November 5, 2020, the patient suffered from thoracic cavity infection. The maximum temperature was $39.1^{\circ} \mathrm{C}$, with cough, greenish-yellow sputum and shortness of breath. The patient was treated with ertapenem, moxifloxacin, the imipenem and cilastatin sodium for injection, piperacillin sodium and tazobactam sodium from November 5 to December 17 successively until the patient's temperature was normal. During the process, the patient was found thyroid dysfunction and tumor progression. The thyroid function was found abnormal on November 11, with FT4 increasing to 43.54 pmol/L, FT3 increasing to $8.33 \mathrm{pmol} / \mathrm{L}, \mathrm{T} 4$ increasing to $14 \mu \mathrm{g} / \mathrm{dL}$, TSH less than $0.001 \mathrm{mIU} / \mathrm{L}$ and TGAb increasing to $223.8 \mathrm{IU} / \mathrm{mL}$. For abnormal thyroid function, immune-related thyroid dysfunction might be the possible cause and there was no treatment given and monitoring was conducted regularly according to the clinical guidelines. 
The chest enhanced CT was performed on December 8, 2020, showing that the maximum diameter of the tumor was $12 \mathrm{~cm}$ and the ipsilateral mediastinal lymph nodes were enlarged (Zone 6), which suggested metastasis might happen. (Figure 1B) The clinical stage was diagnosed asT4N2M0 (IIIB) according to the situation of the patient and the chest CT on December 14, 2020. Unfortunately, the patient cannot get surgery due to tumor progression of left main bronchus and left main pulmonary artery, the RO resection was difficult to achieve. The Performance Status (PS) was 2 at this time. However, the patient refused immunotherapy due to the concerns about the irAEs of immunotherapy.

Since then, the patient received the third cycle chemotherapy with liposomal paclitaxel (240 mg, day 1$)$ plus carboplatin (500 mg, day 1$)$ for the second-line treatment on December 17, 2020. On January 14, 2021, the fourth cycle of chemotherapy was conducted. Meanwhile, the laboratory examination showed the patient had transformed into hypothyroidism, with FT3 decreasing to $1.04 \mathrm{pmol} / \mathrm{L}, \mathrm{FT} 4$ decreasing to $2.84 \mathrm{pmol} / \mathrm{L}$, and TSH increasing to $59.244 \mathrm{mIU} / \mathrm{L}$. Levothyroxine $12.5 \mu \mathrm{g}$ per day (fasting, more than half an hour apart from meals) was given. The dosage was increased to $25 \mu \mathrm{g}$ per day 3 days later, $50 \mu \mathrm{g}$ per day 1 week later, and $75 \mu \mathrm{g}$ per day 2 weeks later. On February 6, 2021, the fifth cycle was conducted. After the treatment of levothyroxine, FT3 returned to 3.19 $\mathrm{pmol} / \mathrm{L}, \mathrm{FT} 4$ returned to $14.69 \mathrm{pmol} / \mathrm{L}$ and TSH returned to $1.811 \mathrm{mIU} / \mathrm{L}$ through examination on February 7,2021 . The changes of thyroid function were shown in Figure 2. The patient continued to take levothyroxine $75 \mu \mathrm{g}$ per day. However, the chest enhanced CT (Figure 1C) showed that the left central lung cancer with invasion of the left pulmonary artery and some branches was more serious than before. Progressive disease (PD) was estimated after the response evaluation for the patient on February 7, 2021. The treatment in second-line showed poor efficacy in this patient. After then, the patient stopped the treatment and died in July 2021. The timeline of the patient's treatment course was shown in figure 3.

\section{Discussion}

Immunotherapy has changed the treatment pattern for NSCLC. Several trials exploring the efficacy and safety of monotherapy ICI or in combination with chemotherapy in neoadjuvant treatment of NSCLC have shown promising results. However, the immune-related adverse events (irAEs) and the poor response to immunotherapy aroused great concern[11,15]. Our study has presented a case of irAEs and tumor progression after the treatment of the PD-1 inhibitor pembrolizumab in combination with chemotherapy. To the best of our knowledge, this is the first reported case of thyroid dysfunction and tumor progression in neoadjuvant immunotherapy for NSCLC.

In this case, ICls in combination with chemotherapy were attempted to be used before surgery. However, the thyroid dysfunction occurred and the patient experienced transient hyperthyroidism then transformed into hypothyroidism. We suspected that this adverse event was induced by ICls as there is no report that carboplatin and gemcitabine caused the thyroid dysfunction to our best knowledge. The causal relationship was assessed as "probable/likely" according to the adverse drug reactions causality assessment methods of WHO Drug monitoring center. Moreover, the patient suffered from tumor progression and was unable to undergo resection. The patient refused immunotherapy and was given chemotherapy for the following treatment.

In trials of resectable NSCLC, previous data showed that the hypothyroidism was the most commonly in ICls-related thyroid dysfunction, varied from 0 to $26.7 \%$ in anti-PD-1 therapy, 4.8-11.1\% in dual-ICl therapy and 0 to $10.0 \%$ in ICls in combination with chemotherapy respectively (Table 1)[16, 7, 9, 17-22]. In addition, combination immunotherapy, baseline thyroid-stimulating hormone, female sex, and pre-existing thyroid disease would be the risk factors associated with immunotherapy related thyroid alterations according to relevant studies.[23-26] 
Table 1

The incidence of thyroid dysfunction and failure to undergo resection of neoadjuvant immunotherapy

\begin{tabular}{|c|c|c|c|c|c|c|c|c|c|c|}
\hline \multirow[t]{2}{*}{ Study } & \multirow[t]{2}{*}{$\mathrm{ICl}$} & \multirow[t]{2}{*}{ Phase } & \multirow[t]{2}{*}{$\mathbf{N}$} & \multicolumn{2}{|c|}{ Thyroid dysfunction } & \multicolumn{5}{|c|}{ Failure to surgery } \\
\hline & & & & Hypothyroidism & Hyperthyroidism & Total & $\begin{array}{l}\text { Disease } \\
\text { progression }\end{array}$ & $\begin{array}{l}\text { Inadequate } \\
\text { lung } \\
\text { function }\end{array}$ & $\begin{array}{l}\text { Unresectable } \\
\text { disease }\end{array}$ & $\begin{array}{l}\text { Location } \\
\text { of tumor }\end{array}$ \\
\hline \multicolumn{11}{|c|}{ ICI monotherapy } \\
\hline $\begin{array}{l}\text { Tong et } \\
\text { al. }\end{array}$ & Pembrolizumab & II & 30 & $3 / 30(10.0 \%)$ & 0 & $\begin{array}{l}5 / 30 \\
(16.7 \%)\end{array}$ & $1 / 30(3.3 \%)$ & 0 & $\begin{array}{l}4 / 30 \\
(13.3 \%)\end{array}$ & 0 \\
\hline $\begin{array}{l}\text { Eichhorn } \\
\text { et al. }\end{array}$ & Pembrolizumab & II & 15 & $4 / 15(26.7 \%)$ & 0 & 0 & 0 & 0 & 0 & 0 \\
\hline Gao et al. & Sintilimab & $\mathrm{lb}$ & 40 & $7 / 40(17.5 \%)$ & $3 / 40(7.5 \%)$ & $\begin{array}{l}3 / 40 \\
(7.5 \%) \\
*\end{array}$ & - & - & - & - \\
\hline $\begin{array}{l}\text { Forde et } \\
\text { al. }\end{array}$ & Nivolumab & II & 22 & 0 & 0 & $\begin{array}{l}1 / 21 \\
(4.8 \%)\end{array}$ & 0 & 0 & 0 & $\begin{array}{l}1 / 21 \\
(4.8 \%)\end{array}$ \\
\hline \multicolumn{11}{|l|}{ Dual-ICl } \\
\hline $\begin{array}{l}\text { Cascone } \\
\text { et al. }\end{array}$ & $\begin{array}{l}\text { Nivolumab } \\
\text { Ipilimumab }\end{array}$ & II & 21 & $1 / 21(4.8 \%)$ & $2 / 21(9.5 \%)$ & $\begin{array}{l}4 / 21 \\
(19.0 \%)\end{array}$ & $1 / 21(4.8 \%)$ & $\begin{array}{l}1 / 21 \\
(4.8 \%)\end{array}$ & $1 / 21(4.8 \%)$ & 0 \\
\hline $\begin{array}{l}\text { Reuss et } \\
\text { al. }\end{array}$ & $\begin{array}{l}\text { Nivolumab } \\
\text { Ipilimumab }\end{array}$ & II & 9 & $1 / 9(11.1)$ & 0 & $\begin{array}{l}3 / 9 \\
(33.3 \%)\end{array}$ & $3 / 9(33.3 \%)$ & 0 & 0 & 0 \\
\hline \multicolumn{11}{|c|}{ Chemotherapy with ICI } \\
\hline $\begin{array}{l}\text { Shen et } \\
\text { al. }\end{array}$ & Pembrolizumab & - & 37 & $1 / 37(2.7 \%)$ & 0 & 0 & 0 & 0 & 0 & 0 \\
\hline Shu et al. & Atezolizumab & II & 30 & $3 / 30(10.0 \%)$ & 0 & $\begin{array}{l}4 / 30 \\
(13.3 \%)\end{array}$ & $1 / 30(3.3 \%)$ & 0 & $\begin{array}{l}3 / 30 \\
(10.0 \%)\end{array}$ & 0 \\
\hline $\begin{array}{l}\text { Provencio } \\
\text { et al. }\end{array}$ & Nivolumab & II & 46 & 0 & 0 & $\begin{array}{l}5 / 46 \\
(10.9 \%)\end{array}$ & 0 & 0 & $3 / 46(6.5 \%)$ & 0 \\
\hline $\begin{array}{l}\text { Tfayli et } \\
\text { al. }\end{array}$ & Avelumab & II & 15 & 0 & 0 & $\begin{array}{l}4 / 15 \\
(26.7 \%)\end{array}$ & $1 / 15(6.7 \%)$ & $\begin{array}{l}3 / 15 \\
(20.0 \%)\end{array}$ & 0 & 0 \\
\hline $\begin{array}{l}\text { Yang et } \\
\text { al. }\end{array}$ & Ipilimumab & II & 24 & 0 & 0 & $\begin{array}{l}11 / 24 \\
(45.8 \%)\end{array}$ & $2 / 24(8.3 \%)$ & $2 / 24(8.3 \%)$ & $5 / 24(20.8 \%)$ & $1 / 24(4.2 \%)$ \\
\hline
\end{tabular}

Note: *This study did not report on the specific reason for a patient not to proceed to the planned surgery.

Given the incidence of the thyroid dysfunction, it is critical for us to master the clinical manifestations and management. The majority of thyroid dysfunction is asymptomatic or mild, and those with symptoms mostly presented with hypothyroidism, such as fatigue, anorexia, constipation, bradycardia or weight gain[27, 28]. Some patients initially present with hyperthyroidism, manifested as palpitations, sweating, fear of heat, diarrhea, tremor, and wasting, almost $50-$ $90 \%$ of them undergo a brief hyperthyroidism period (usually a median of 1 month) and then turn to hypothyroidism[28].

The median onset time of hypothyroidism in advanced settings was 63 days (range from 24 to 141 days) and 70 days (range from 27 to 475 days) in the dual-ICl and monotherapy groups, respectively. Whereas the occurrence of thyrotoxicosis followed by hypothyroidism was 63 days (range from 35 to 141 days) and 84 days (range from 63 to 475 days) in the dual-ICl and monotherapy groups, respectively[29]. In our case, the patient was found hyperthyroidism after 44 days of $\mathrm{ICl}$ therapy and hypothyroidism was found after 106 days of ICl therapy.

The mechanism of ICls-related thyroid dysfunction is still unclear. The hypothesis that the normal organs, tissues, and cells could be attacked when ICls kill tumor cell might be the possible mechanism. ICls might trigger T cell-mediated pathways that cause thyroid dysfunction subsequently[30, 31]. The clinical management of thyroid injury caused by ICls should be determined by whether clinical symptoms occur, the type of thyroid dysfunction and the grade of thyroid dysfunction in the National Cancer Institute Common Terminology Criteria for Adverse Events (CTCAE) Version 5.0. [32]. The therapy regimens should be jointly formulated by endocrinologists and oncologists.

Unfortunately, tumor progression happened in this patient and he lost the surgery chance. In trials of neoadjuvant immunotherapy, the rates of failure to surgery ranged from 0 to $17 \%$ in anti-PD-1 therapy, 0 to $46 \%$ in ICls in combination with chemotherapy and $19-33 \%$ in dual-ICl therapy respectively (Table 1 ) $[16,7,9,17-22]$. Disease progression, inadequate lung function, unresectable disease, adverse events, location of tumor, or patient refusal might be the reasons that patient cannot undergo resection[11]. In our case, the disease progression contributed to the failure to undergo resection, which suggested that there was a great need for biomarker to predict the efficacy of the immunotherapy.

In addition, previous data showed that irAEs might be associated with better clinical outcomes[33], and the association between thyroid dysfunction and cancer outcomes has aroused great attention as thyroid dysfunction is among the most common irAE. Studies investigating the association between thyroid dysfunction and survival outcomes were shown in Table $2[34-36,13,37-39,14]$. Previous data suggested that the development of thyroid dysfunction was 
associated with improved outcomes and might serve as a predictive factor of therapy response. This association might be the result of the antigens shared between melanoma cells and normal melanocytes[13, 33, 37].

Table 2

Studies investigating the association of thyroid dysfunction with survival outcomes.

\begin{tabular}{|c|c|c|c|c|}
\hline Study & $\mathbf{N}$ & $\mathrm{ICl}$ & Cancer & Outcome \\
\hline \multirow[t]{2}{*}{ Basak et al [34] } & 168 & Nivolumab or Pembrolizumab & $\begin{array}{l}\text { Metastatic melanoma; NSCLC; and renal cell } \\
\text { carcinoma }\end{array}$ & $\begin{array}{l}\text { OS-HR: } 0.18(0.04-0.76) ; P= \\
0.020 ;\end{array}$ \\
\hline & & & & $\begin{array}{l}\text { PFS-HR: } 0.39(0.15-0.998) ; P= \\
0.050\end{array}$ \\
\hline \multirow[t]{2}{*}{ Luo et al [35] } & 744 & Anti-PD-(L)1 monotherapy or & NSCLC & PFS-HR: $0.68(0.52-0.88)$ \\
\hline & & $\begin{array}{l}\text { Anti-PD-(L) } 1 \text { and CTLA-4 } \\
\text { combination }\end{array}$ & & \\
\hline \multirow[t]{2}{*}{ Kim et al [36] } & 58 & Nivolumab or Pembrolizumab & NSCLC & $\begin{array}{l}\text { OS-HR: } 0.11(0.01-0.92) ; P= \\
0.041 ;\end{array}$ \\
\hline & & & & $\begin{array}{l}\text { PFS-HR: } 0.38(0.17-0.85) ; P= \\
0.018\end{array}$ \\
\hline Osorio et al [13] & 51 & Pembrolizumab & NSCLC & OS-HR: $0.29(0.09-0.94) ; P=0.04$ \\
\hline \multirow[t]{2}{*}{$\begin{array}{l}\text { Thuillier et al } \\
\text { [37] }\end{array}$} & 134 & Nivolumab & NSCLC & $\begin{array}{l}\text { OS-HR: } 0.32(0.16-0.62) ; \mathrm{P}< \\
0.001 ;\end{array}$ \\
\hline & & & & $\begin{array}{l}\text { PFS-HR: } 0.36(0.21-0.62) ; \mathrm{P}< \\
0.001\end{array}$ \\
\hline \multirow[t]{2}{*}{ Zhou et al [38] } & 191 & Nivolumab or Pembrolizumab & NSCLC & OS-HR: 0.356; $P<0.001$; \\
\hline & & & & PFS-HR: $0.393, P<0.001$ \\
\hline \multirow{2}{*}{$\begin{array}{l}\text { D'Aiello et al } \\
\text { [39] }\end{array}$} & 205 & Pembrolizumab or Nivolumab or & Lung cancer & PFS: $P=0.353$ \\
\hline & & Durvalumab or Atezolizumab & & \\
\hline \multirow[t]{2}{*}{ Percik et al [14] } & 208 & Anti-PD-(L)1 monotherapy or & NSCLC & OS-HR: $0.87(0.63-1.20)$ \\
\hline & & $\begin{array}{l}\text { Anti-PD-(L) } 1 \text { and CTLA- } 4 \\
\text { combination }\end{array}$ & & \\
\hline
\end{tabular}

However, another study showed that there was no significant trend toward improved survival in patients who developed thyroid dysfunction in NSCLC patients[14]. In our case, the patient has developed the hypothyroidism while the prognosis is poor. Whether there is a specific association between the antithyroid immunity and the anti-tumor immunity is unclear and larger randomized studies and basal experimental studies are needed to illustrated this question.

There are also some limitations in our case report. At first, the failure to undergo resection was associated with the tumor progression of the patient rather than the irAEs, which indicated that the patient showed poor response to the immunotherapy plus chemotherapy and the biomarker of the neoadjuvant therapy needed further study. Another limitation in our study is the fact that numerous phase II/III clinical trials are still undergoing for investigation of the safety and efficacy of neoadjuvant immunotherapy in resectable NSCLC patients. Long-term follow-up of these studies are needed to define the role of neoadjuvant immunotherapy in resectable NSCLC.

\section{Conclusion}

In conclusion, although results of clinical trials of neoadjuvant immunotherapy have shown potential pathological benefits in resectable NSCLC for patients, irAEs cannot be ignored and tumor progression might happen. Our case has presented the clinical features of thyroid dysfunction and tumor progression, calling for timely and proper monitoring the efficacy and safety of neoadjuvant immunotherapy in resectable NSCLC. We also presented the case that the development of thyroid dysfunction cannot predict the better therapy response of ICls.

\section{Abbreviations}

Common Terminology Criteria for Adverse Events (CTCAE)

Eastern Cooperative Oncology Group Performance Status (ECOG PS)

free triiodothyronine (FT3)

free thyroxine (FT4)

immune checkpoint inhibitors (ICls)

immune-related adverse events (irAEs) 
non-small cell lung cancer (NSCLC)

progressive disease (PD)

programmed death receptor 1 (PD-1) and its ligand (PD-L1)

thyroglobulin antibodies (TGAb)

thyroid stimulating hormone (TSH)

\section{Declarations}

\section{O Ethics approval and consent to participate}

The study was approved by the Ethics Committee of Peking University People's Hospital (Approved number: 2021PHB018-001) and was conducted in accordance with the Declaration of Helsinki. Informed consent was obtained from the patient' relative for participating in this study.

\section{Consent for publication}

Informed consent was obtained from the patient' relative.

\section{Availability of data and materials}

All data relevant to this study are included in this published article.

\section{Competing interests}

The authors have no disclosures and no competing interests.

\section{O Funding}

Bethune Charitable Foundation of Pharmaceutical Research Capacity Building Project(B-19-H-20200622).

\section{O Authors' contributions}

The contributions were made by all authors. Xinyi Li and Xun Wang contributed to the identification and selection of case and the first draft of the manuscript. Yi Liu, Ruilin Wang, Lin Huang, Yufei Feng, Xiaohui Xie, and Luwen Shi drafted the initial manuscript. Xun Wang, Shaodong Wang, and Yanguo Liu contributed to the management of the patient and edited the manuscript. All authors read the article and approved the final version.

\section{O Acknowledgements}

We thank the patient and his family for participating in the study.

\section{O Authors' information}

\section{Department of Pharmacy Administration and Clinical Pharmacy, School of Pharmaceutical Sciences, Peking University, Beijing, China}

Xinyi Li, Ruilin Wang, Xiaohui Xie \&Luwen Shi

People's Hospital, Peking University, Beijing, China

Xun Wang, Shaodong Wang, Yanguo Liu, Yi Liu, Lin Huang \&Yufei Feng

- Compliance with Ethical Standards

\section{O Disclosure of potential conflicts of interest}

The authors declare that they have no conflict of interest.

\section{O Research involving Human Participants and/or Animals}

The study was approved by the Ethics Committee of Peking University People's Hospital (Approved number: 2021PHB018-001) and was conducted in accordance with the Declaration of Helsinki.

\section{O Informed consent}

Informed consent was obtained from the patient' relative.

\section{References}


1. Sung H, Ferlay J, Siegel RL, Laversanne M, Soerjomataram I, Jemal A, Bray F (2021) Global Cancer Statistics 2020: GLOBOCAN Estimates of Incidence and Mortality Worldwide for 36 Cancers in 185 Countries. CA Cancer J Clin 71(3):209-249. doi:10.3322/caac.21660

2. Goldstraw P, Chansky K, Crowley J, Rami-Porta R, Asamura H, Eberhardt WE, Nicholson AG, Groome P, Mitchell A, Bolejack V (2016) The IASLC Lung Cancer Staging Project: Proposals for Revision of the TNM Stage Groupings in the Forthcoming (Eighth) Edition of the TNM Classification for Lung Cancer. J Thorac Oncol 11(1):39-51. doi:10.1016/j.jtho.2015.09.009

3. Uramoto H, Tanaka F (2014) Recurrence after surgery in patients with NSCLC. Transl Lung Cancer Res 3(4):242-249. doi:10.3978/j.issn.22186751.2013 .12 .05

4. Preoperative chemotherapy for non-small-cell lung cancer: a systematic review and meta-analysis of individual participant data (2014).Lancet383 (9928):1561-1571. doi: 10.1016/s0140-6736(13)62159-5

5. Garon EB, Hellmann MD, Rizvi NA, Carcereny E, LeighI NB, Ahn MJ, Eder JP, Balmanoukian AS, Aggarwal C, Horn L, Patnaik A, Gubens M, Ramalingam SS, Felip E, Goldman JW, Scalzo C, Jensen E, Kush DA, Hui R (2019) Five-Year Overall Survival for Patients With Advanced Non-Small-Cell Lung Cancer Treated With Pembrolizumab: Results From the Phase I KEYNOTE-001 Study. J Clin Oncol 37(28):2518-2527. doi:10.1200/jco.19.00934

6. Mok TSK, Wu YL, Kudaba I, Kowalski DM, Cho BC, Turna HZ, Castro G Jr, Srimuninnimit V, Laktionov KK, Bondarenko I, Kubota K, Lubiniecki GM, Zhang J, Kush D, Lopes G (2019) Pembrolizumab versus chemotherapy for previously untreated, PD-L1-expressing, locally advanced or metastatic non-small-cell lung cancer (KEYNOTE-042): a randomised, open-label, controlled, phase 3 trial. Lancet 393(10183):1819-1830. doi:10.1016/s0140-6736(18)32409-7

7. Forde PM, Chaft JE, Smith KN, Anagnostou V, Cottrell TR, Hellmann MD, Zahurak M, Yang SC, Jones DR, Broderick S, Battafarano RJ, Velez MJ, Rekhtman N, Olah Z, Naidoo J, Marrone KA, Verde F, Guo H, Zhang J, Caushi JX, Chan HY, Sidhom JW, Scharpf RB, White J, Gabrielson E, Wang H, Rosner GL, Rusch V, Wolchok JD, Merghoub T, Taube JM, Velculescu VE, Topalian SL, Brahmer JR, Pardoll DM (2018) Neoadjuvant PD-1 Blockade in Resectable Lung Cancer. N Engl J Med 378(21):1976-1986. doi:10.1056/NEJMoa1716078

8. Cascone T, William WN Jr, Weissferdt A, Leung CH, Lin HY, Pataer A, Godoy MCB, Carter BW, Federico L, Reuben A, Khan MAW, Dejima H, Francisco-Cruz A, Parra ER, Solis LM, Fujimoto J, Tran HT, Kalhor N, Fossella FV, Mott FE, Tsao AS, Blumenschein G Jr, Le X, Zhang J, Skoulidis F, Kurie JM, Altan M, Lu C, Glisson BS, Byers LA, Elamin YY, Mehran RJ, Rice DC, Walsh GL, Hofstetter WL, Roth JA, Antonoff MB, Kadara H, Haymaker C, Bernatchez C, Ajami NJ, Jenq RR, Sharma P, Allison JP, Futreal A, Wargo JA, Wistuba II, Swisher SG, Lee JJ, Gibbons DL, Vaporciyan AA, Heymach JV, Sepesi B (2021) Neoadjuvant nivolumab or nivolumab plus ipilimumab in operable non-small cell lung cancer: the phase 2 randomized NEOSTAR trial. Nat Med 27(3):504-514. doi:10.1038/s41591-020-01224-2

9. Gao S, Li N, Gao S, Xue Q, Ying J, Wang S, Tao X, Zhao J, Mao Y, Wang B, Shao K, Lei W, Wang D, Lv F, Zhao L, Zhang F, Zhao Z, Su K, Tan F, Gao Y, Sun N, Wu D, Yu Y, Ling Y, Wang Z, Duan C, Tang W, Zhang L, He S, Wu N, Wang J, He J (2020) Neoadjuvant PD-1 inhibitor (Sintilimab) in NSCLC. J Thorac Oncol 15(5):816-826. doi:10.1016/j.jtho.2020.01.017

10. Kang J, Zhang C, Zhong WZ (2021) Neoadjuvant immunotherapy for non-small cell lung cancer: State of the art. Cancer Commun (Lond) 41(4):287-302. doi:10.1002/cac2.12153

11. Ulas EB, Dickhoff C, Schneiders FL, Senan S, Bahce I (2021) Neoadjuvant immune checkpoint inhibitors in resectable non-small-cell lung cancer: a systematic review. ESMO Open 6(5):100244. doi:10.1016/j.esmoop.2021.100244

12. Wright JJ, Powers AC, Johnson DB (2021) Endocrine toxicities of immune checkpoint inhibitors. Nat Rev Endocrinol 17(7):389-399. doi:10.1038/s41574021-00484-3

13. Osorio JC, Ni A, Chaft JE, Pollina R, Kasler MK, Stephens D, Rodriguez C, Cambridge L, Rizvi H, Wolchok JD, Merghoub T, Rudin CM, Fish S, Hellmann MD (2017) Antibody-mediated thyroid dysfunction during T-cell checkpoint blockade in patients with non-small-cell lung cancer. Ann Oncol 28(3):583-589. doi:10.1093/annonc/mdw640

14. Percik R, Liel Y, Urban D, Bar J, Ben-Ami E, Abu Tailakh M (2021) Thyroid dysfunction and survival in cancer patients treated with immune checkpoint inhibitors: analyses from a large single tertiary cancer center database. Acta Oncol 60(11):1466-1471. doi:10.1080/0284186x.2021.1958006

15. Soh J, Hamada A, Fujino T, Mitsudomi T (2021) Perioperative Therapy for Non-Small Cell Lung Cancer with Immune Checkpoint Inhibitors. Cancers (Basel) 13(16). doi:10.3390/cancers13164035

16. Eichhorn F, Klotz LV, Kriegsmann M, Bischoff H, Schneider MA, Muley T, Kriegsmann K, Haberkorn U, Heussel CP, Savai R, Zoernig I, Jaeger D, Thomas M, Hoffmann H, Winter H, Eichhorn ME (2021) Neoadjuvant anti-programmed death-1 immunotherapy by pembrolizumab in resectable non-small cell lung cancer: First clinical experience. Lung Cancer 153:150-157. doi:10.1016/j.lungcan.2021.01.018

17. Tong BC, Gu L, Wang X, Wigle DA, Phillips JD, Harpole DH Jr, Klapper JA, Sporn T, Ready NE, D'Amico TA (2021) Perioperative outcomes of pulmonary resection after neoadjuvant pembrolizumab in patients with non-small cell lung cancer. J Thorac Cardiovasc Surg. doi:10.1016/j.jtcvs.2021.02.099

18. Shen D, Wang J, Wu J, Chen S, Li J, Liu J, Chen Q, Jiang Y (2021) Neoadjuvant pembrolizumab with chemotherapy for the treatment of stage IIB-IIIB resectable lung squamous cell carcinoma. J Thorac Dis 13(3):1760-1768. doi:10.21037/jtd-21-103

19. Provencio M, Nadal E, Insa A, García-Campelo MR, Casal-Rubio J, Dómine M, Majem M, Rodríguez-Abreu D, Martínez-Martí A, De Castro Carpeño J, Cobo M, López Vivanco G, Del Barco E, Bernabé Caro R, Viñolas N, Barneto Aranda I, Viteri S, Pereira E, Royuela A, Casarrubios M, Salas Antón C, Parra ER, Wistuba I, Calvo V, Laza-Briviesca R, Romero A, Massuti B, Cruz-Bermúdez A (2020) Neoadjuvant chemotherapy and nivolumab in resectable non-smallcell lung cancer (NADIM): an open-label, multicentre, single-arm, phase 2 trial. Lancet Oncol 21(11):1413-1422. doi:10.1016/s1470-2045(20)30453-8

20. Shu CA, Gainor JF, Awad MM, Chiuzan C, Grigg CM, Pabani A, Garofano RF, Stoopler MB, Cheng SK, White A, Lanuti M, D'Ovidio F, Bacchetta M, Sonett JR, Saqi A, Rizvi NA (2020) Neoadjuvant atezolizumab and chemotherapy in patients with resectable non-small-cell lung cancer: an open-label, multicentre, single-arm, phase 2 trial. Lancet Oncol 21(6):786-795. doi:10.1016/s1470-2045(20)30140-6

21. Tfayli A, Al Assaad M, Fakhri G, Akel R, Atwi H, Ghanem H, El Karak F, Farhat F, Al Rabi K, Sfeir P, Youssef P, Mansour Z, Assi H, Haidar M, Abi Ghanem A, Khalifeh I, Boulos F, Mahfouz R, Youssef B, Zeidan Y, Bejjany R, Khuri F (2020) Neoadjuvant chemotherapy and Avelumab in early stage resectable 
nonsmall cell lung cancer. Cancer Med 9(22):8406-8411. doi:10.1002/cam4.3456

22. Yang CJ, McSherry F, Mayne NR, Wang X, Berry MF, Tong B, Harpole DH Jr, D'Amico TA, Christensen JD, Ready NE, Klapper JA (2018) Surgical Outcomes After Neoadjuvant Chemotherapy and Ipilimumab for Non-Small Cell Lung Cancer. Ann Thorac Surg 105(3):924-929. doi:10.1016/j.athoracsur.2017.09.030

23. Presotto EM, Rastrelli G, Desideri I, Scotti V, Gunnella S, Pimpinelli N, Vaccher E, Bearz A, Di Costanzo F, Bruggia M, Mini E, Maggi M, Peri A (2020) Endocrine toxicity in cancer patients treated with nivolumab or pembrolizumab: results of a large multicentre study. J Endocrinol Invest 43(3):337-345. doi:10.1007/s40618-019-01112-8

24. Li M, Hou X, Chen J, Yu J, Chen M, Wang N, Zhang B, Chen L (2021) Comparing organ-specific immune-related adverse events for immune checkpoint inhibitors: A Bayesian network meta-analysis. Clin Transl Med 11(2):e291. doi:10.1002/ctm2.291

25. Rubino R, Marini A, Roviello G, Presotto EM, Desideri I, Ciardetti I, Brugia M, Pimpinelli N, Antonuzzo L, Mini E, Livi L, Maggi M, Peri A (2021) Endocrinerelated adverse events in a large series of cancer patients treated with anti-PD1 therapy. Endocrine 74(1):172-179. doi:10.1007/s12020-021-02750-W

26. Muir CA, Clifton-Bligh RJ, Long GV, Scolyer RA, Lo SN, Carlino MS, Tsang VHM, Menzies AM (2021) Thyroid Immune-related Adverse Events Following Immune Checkpoint Inhibitor Treatment. J Clin Endocrinol Metab 106(9):e3704-e3713. doi:10.1210/clinem/dgab263

27. Morganstein DL, Lai Z, Spain L, Diem S, Levine D, Mace C, Gore M, Larkin J (2017) Thyroid abnormalities following the use of cytotoxic T-lymphocyte antigen-4 and programmed death receptor protein-1 inhibitors in the treatment of melanoma. Clin Endocrinol (0xf) 86(4):614-620. doi:10.1111/cen.13297

28. Walters AGB, Braatvedt G (2021) Endocrine adverse effects of immune checkpoint inhibitors. Intern Med J 51(7):1016-1020. doi:10.1111/imj.14992

29. Lee H, Hodi FS, Giobbie-Hurder A, Ott PA, Buchbinder El, Haq R, Tolaney S, Barroso-Sousa R, Zhang K, Donahue H, Davis M, Gargano ME, Kelley KM, Carroll RS, Kaiser UB, Min L (2017) Characterization of Thyroid Disorders in Patients Receiving Immune Checkpoint Inhibition Therapy. Cancer Immunol Res 5(12):1133-1140. doi:10.1158/2326-6066.Cir-17-0208

30. Zhan L, Feng HF, Liu HQ, Guo LT, Chen C, Yao XL, Sun SR (2021) Immune Checkpoint Inhibitors-Related Thyroid Dysfunction: Epidemiology, Clinical Presentation, Possible Pathogenesis, and Management. Front Endocrinol (Lausanne) 12:649863. doi:10.3389/fendo.2021.649863

31. Delivanis DA, Gustafson MP, Bornschlegl S, Merten MM, Kottschade L, Withers S, Dietz AB, Ryder M (2017) Pembrolizumab-Induced Thyroiditis: Comprehensive Clinical Review and Insights Into Underlying Involved Mechanisms. J Clin Endocrinol Metab 102(8):2770-2780. doi:10.1210/jc.201700448

32. Schneider BJ, Naidoo J, Santomasso BD, Lacchetti C, Adkins S, Anadkat M, Atkins MB, Brassil KJ, Caterino JM, Chau I, Davies MJ, Ernstoff MS, Fecher L, Ghosh M, Jaiyesimi I, Mammen JS, Naing A, Nastoupil LJ, Phillips T, Porter LD, Reichner CA, Seigel C, Song JM, Spira A, Suarez-Almazor M, Swami U, Thompson JA, Vikas P, Wang Y, Weber JS, Funchain P, Bollin K (2021) Management of Immune-Related Adverse Events in Patients Treated With Immune Checkpoint Inhibitor Therapy: ASCO Guideline Update. J Clin Oncol 39(36):4073-4126. doi:10.1200/jco.21.01440

33. Haratani K, Hayashi H, Chiba Y, Kudo K, Yonesaka K, Kato R, Kaneda H, Hasegawa Y, Tanaka K, Takeda M, Nakagawa K (2018) Association of ImmuneRelated Adverse Events With Nivolumab Efficacy in Non-Small-Cell Lung Cancer. JAMA Oncol 4(3):374-378. doi:10.1001/jamaoncol.2017.2925

34. Basak EA, van der Meer JWM, Hurkmans DP, Schreurs MWJ, Oomen-de Hoop E, van der Veldt AAM, Bins S, Joosse A, Koolen SLW, Debets R, Peeters RP, Aerts J, Mathijssen RHJ, Medici M (2020) Overt Thyroid Dysfunction and Anti-Thyroid Antibodies Predict Response to Anti-PD-1 Immunotherapy in Cancer Patients. Thyroid 30(7):966-973. doi:10.1089/thy.2019.0726

35. Luo J, Martucci VL, Quandt Z, Groha S, Murray MH, Lovly CM, Rizvi H, Egger JV, Plodkowski AJ, Abu-Akeel M, Schulze I, Merghoub T, Cardenas E, Huntsman S, Li M, Hu D, Gubens MA, Gusev A, Aldrich MC, Hellmann MD, Ziv E (2021) Immunotherapy-Mediated Thyroid Dysfunction: Genetic Risk and Impact on Outcomes with PD-1 Blockade in Non-Small Cell Lung Cancer. Clin Cancer Res 27(18):5131-5140. doi:10.1158/1078-0432.Ccr-21-0921

36. Kim HI, Kim M, Lee SH, Park SY, Kim YN, Kim H, Jeon MJ, Kim TY, Kim SW, Kim WB, Kim SW, Lee DH, Park K, Ahn MJ, Chung JH, Shong YK, Kim WG, Kim TH (2017) Development of thyroid dysfunction is associated with clinical response to PD-1 blockade treatment in patients with advanced non-small cell lung cancer. Oncoimmunology 7(1):e1375642. doi:10.1080/2162402x.2017.1375642

37. Thuillier P, Joly C, Alavi Z, Crouzeix G, Descourt R, Quere G, Kerlan V, Roudaut N (2021) Thyroid dysfunction induced by immune checkpoint inhibitors is associated with a better progression-free survival and overall survival in non-small cell lung cancer: an original cohort study. Cancer Immunol Immunother 70(7):2023-2033. doi:10.1007/s00262-020-02802-6

38. Zhou Y, Xia R, Xiao H, Pu D, Long Y, Ding Z, Liu J, Ma X (2021) Thyroid function abnormality induced by PD-1 inhibitors have a positive impact on survival in patients with non-small cell lung cancer. Int Immunopharmacol 91:107296. doi:10.1016/j.intimp.2020.107296

39. D'Aiello A, Lin J, Gucalp R, Tabatabaie V, Cheng H, Bloomgarden NA, Tomer Y, Halmos B (2021) Thyroid Dysfunction in Lung Cancer Patients Treated with Immune Checkpoint Inhibitors (ICls): Outcomes in a Multiethnic Urban Cohort. Cancers (Basel) 13(6). doi:10.3390/cancers13061464

\section{Figures}




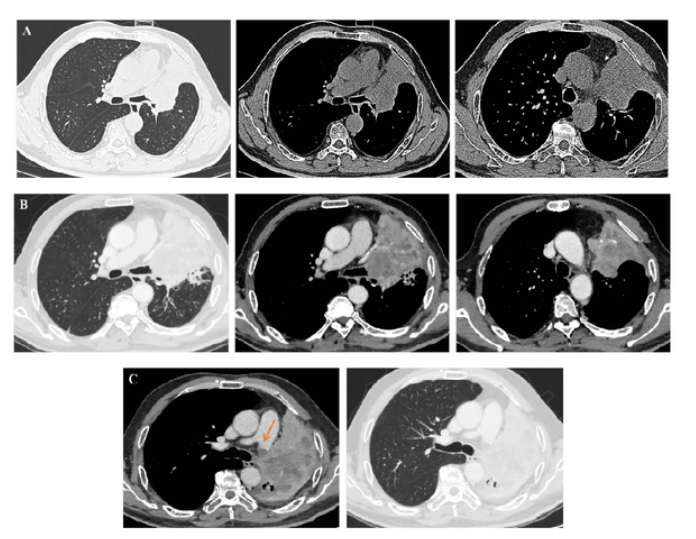

Figure 1

The chest $\mathrm{CT}$ of the patient during the therapy

Note: (A). Before the therapy in September 27, 2020, (B). After the second cycle of neoadjuvant immunotherapy in combination with chemotherapy in December 8, 2021, and (C). After the fifth cycle of chemotherapy in February 7, 2021 


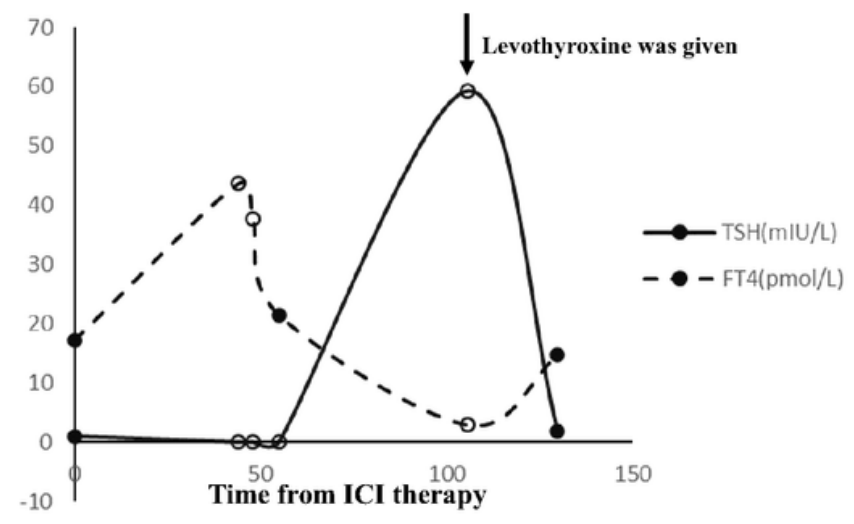

Figure 2

The changes of thyroid function for the patient during the therapy

Note: The normal value interval of TSH is from 0.55 to $4.78 \mathrm{mlU} / \mathrm{L}$ and the normal value interval of FT4 is from 11.45 to $23.17 \mathrm{pmol} / \mathrm{L}$. The Solid label indicated that the laboratorial index was in the normal range.

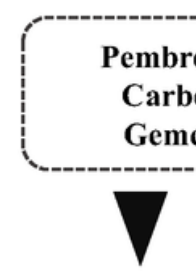

Pembrolizumab (200 mg d1)

Carboplatin (450 mg d1)

Gemcitabine (2.2 g d1,8)

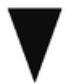

$29 / 9 / 2020$

$20 / 10 / 2020$

$11 / 11 / 2020$

$17 / 12 / 2020$

Paclitaxel (240 mg d1)

Carboplatin (500 mg d1)

\section{Neoadjuvant ICI-chemo, Neoadjuvant ICI-chemo,} first cycle second cycle

\section{Monitor the thyroid function

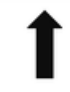 \\ Hyperthyroidism without symptoms}

Chemo, third cycle

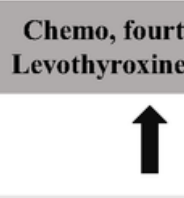

T4N0M0

(IIIA)

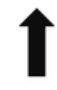

T4N2M0

(IIIB)

estimated

\section{Hypothyroidism \\ with TSH $>10 \mathrm{mIU} / \mathrm{L}$}

Refused

07/2021

Death

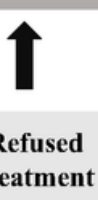


Figure 3

The timeline of the patient's treatment course

Page $11 / 11$ 